\title{
An Economic Inquisition of Water Quality Trading Programs, with a Case Study of Jordan Lake, NC
}

\begin{abstract}
A water quality trading (WQT) program was promulgated in North Carolina to address water quality issues related to nutrients in the highly urbanizing Jordan Lake Watershed. Although WQT programs are appealing in theory, the concept has not proved feasible in several attempts between point and nonpoint polluters in the United States. Many application hurdles that create wedges between success and failure have been evaluated in the literature. Most programs, however, face multiple hurdles; eliminating one may not clear a pathway to success. Therefore, we identify and evaluate the combined impact of four different wedges including baseline, transaction cost, trading ratio, and trading cost in the Jordan Lake Watershed program. Unfortunately, when applied to the Jordan Lake program, the analysis clearly shows that a traditional WQT program will not be feasible or address nutrient management needs in a meaningful way. The hurdles individually would be difficult to overcome, but together they appear to be unsurmountable. This analysis shows that there is enough information to preidentify potential hurdles that could inform policy makers where, and how, the concept might work. It would have saved time, energy, and financial resources if North Carolina had done so before embarking to implement their program in the Jordan Lake Watershed.
\end{abstract}

\section{Keywords}

Water quality trading; Non-point sources; Wedges; Jordan Lake; North Carolina 


\section{Introduction}

Over half of lakes, reservoirs, and ponds assessed in the United States are threatened or impaired by different types of nutrients (Selman et al. 2009). Many different policies have been used to improve water quality, including the increasingly popular concept of water quality trading (WQT). In theory, water quality can be improved at a lower cost using WQT than with other types of policies, such as command and control, by allowing individuals or firms with high abatement costs to trade credits with firms that have low marginal abatement costs (EPA, 2008; EPA handbook, 2004; Faeth, 2000; Greenhalgh and Selman, 2012; Willamette Partnership, 2014).

Although WQT is appealing in theory, WQT programs in the United States have struggled to show any meaningful success, especially when including non-point sources (NPSs) from farms (Smith, 2011; Shortle, 2013a; Ribaudo and Gottlieb, 2011). For example, Morgan and Wolverton (2005) found that out of 19 WQT programs in the USA, only four had experienced more than three trades. A growing body of literature suggests that achieving an ideal WQT market is difficult because WQT programs have implementation hurdles that seriously impede or even preclude their success (Breetz et al. 2004, 2005; Hennessy and Feng, 2008; Hoag and Hughes-Popp, 1997; Horan, 2001; Jarvie and Solomon, 1998; King, 2005; Malik et al. 1993; Newburn and Woodward, 2012; Ribaudo, et al. 1999; Ribaudo and Gottlieb, 2011; Shabman and Stephenson, 2002; Stephenson and Norris, 1998; Stavins, 1995; Suter et al. 2011). However, to the best of our knowledge, no study has provided a comprehensive understanding of how these hurdles work together, either independently or with interactions, to make or break a market. Costly errors could be made if policy makers overcome one of these hurdles just to discover another hurdle follows - and another. The few programs that have found limited success have done so by skillfully navigating these hurdles (e.g., the Great Miami Trading Program in Ohio (Newburn and Woodword, 2012)).

A WQT market can be portrayed in a familiar supply-demand format. King and Kuch (2003) postulated that there might be three types of markets. If the credit supply and demand cross each other, an ideal (i.e., frictionless (Smith et al., 2012)) market is possible. If there are hurdles, they act as wedges, driving supply and demand apart and creating a marginal market. A marginal market might be able to function if the wedges do not fully drive supply and demand apart, which would be an infeasible market. 
The purpose of this study is to build an economic framework to examine multiple wedges simultaneously to investigate how these wedges effect a WQT market. We build supply and demand curves for an ideal market related to an existing program then add wedges to determine how they affect trading. Our case study is in the Jordan Lake Watershed where the State of North Carolina (NC) is currently attempting to implement a market for trading nutrients to improve water quality. This paper contributes to the literature by providing a structured framework to study wedges that may arise when WQT programs are implemented. Using this framework, wedges may be anticipated and evaluated in a comprehensive way to determine the combined effect on market viability before WQT programs are implemented. Markets with high potential to fail may be avoided where research shows that the combined effect of policy wedges is too great to overcome. The totality of how policy wedges stack up offers one explanation about why successful WQT markets are so elusive. In our case study, we demonstrate empirical estimation of the supply and demand, as well as evaluation of the impacts of four different wedges on supply and demand, to show why a functional WQT market in this study area is unlikely to succeed. This work should help policy makers determine a more precise setting for designing WQT programs and give some insight on how to implement policies that reduce the magnitude of any wedges where possible.

\section{Study area and methods}

We proceed by building a framework to determine supply and demand in an ideal WQT market. We then build a marginalized market by introducing four of the most important wedges discussed in the literature. These include: how baseline is defined, transaction costs, the existence of trading costs, and policies that impose trading ratios. Lastly, we estimate an empirical supply and demand for credit trading in the Jordan Lake Watershed program, and apply empirical estimates for each of the same wedges to predict the potential for success in this emerging WQT market. In the end, we estimate whether that market is sufficiently marginalized to fail.

The Jordan Lake Watershed, located in the Piedmont region of North Carolina, is a significant water resource within the Cape Fear River Basin (Figure 1). In addition to serving as a crucial water supply, Jordan Lake was created to provide flood control, protection of water quality downstream, fish and wildlife conservation, and recreation services. Since its 
impoundment, the lake has been declared as hyper-eutrophic by the Environmental Management Commission (NCDEQ, 2014).

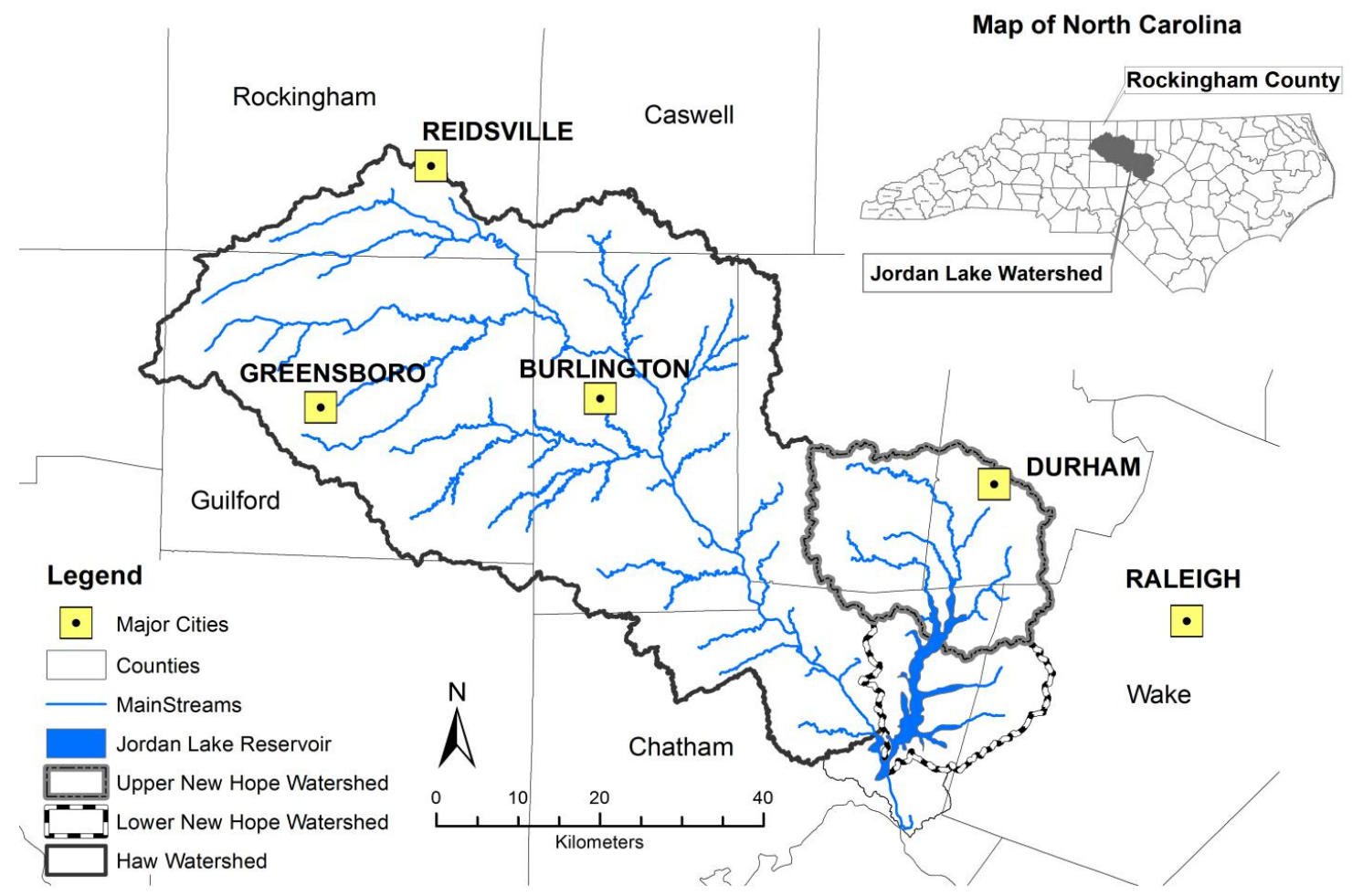

Fig. 1. Jordan Lake Watershed study area.

We develop a mixed empirical and hypothetical model based on actual WQT program rules and goals, and then evaluate credit trading behavior based on cost and pollution data for individual farms in the Haw sub-watershed (which comprises $80 \%$ of the Jordan Lake Watershed area). In the Jordan Lake WQT program farmers can install riparian buffers as a conservation practice $(\mathrm{CP})$ to reduce total nitrogen $(\mathrm{TN})$ loads delivered to the lake, and sell credits for this pollutant reduction to new urban developers. In this program, new urban developers are held responsible for reducing the TN loads to the lake, while farmers' participation in this program is voluntary.

We begin by determining urban demand for credits. Urban developers minimize the cost to reduce expected TN loading to Jordan Lake as follows (Malik, et al 1993):

$$
\begin{aligned}
& \min _{T N_{u}}\left[T C\left(T N_{u}\right)\right] \\
& \text { s.t. } E\left[T N_{u}\right] \leq \overline{T N}
\end{aligned}
$$


$T N_{u}$ denotes the urban developers' allowed TN loads to Jordan Lake, based on the WQT rules, and $T C\left(T N_{u}\right)$ is the urban abatement cost function that is decreasing and strictly convex in loading $T N_{u}$. The constraint restricts expected $T N_{u}$, or $E\left[T N_{u}\right]$, to be no greater than the target level $\overline{T N}$. We assume the $T C\left(T N_{u}\right)$ properties will ensure the minimization condition and an interior solution will be obtained.

Developers have two options to minimize their total costs. They can either (1) install or upgrade waste water treatment plants (WWTP) for TN reduction $\left(T N R_{t e c h}\right)$ or (2) participate in a WQT program to buy credits for TN reduction ( $\left.T N R_{\text {trade }}\right)$. Therefore, urban developers' total cost, $\operatorname{TC}\left(T N_{u}\right)$, for achieving their water quality requirements is as follows:

$$
T C\left(T N_{u}\right)=f\left(T N R_{\text {tech }}, t * T N R_{\text {trade }}\right)
$$

Where $T N R_{\text {tech }}$ and $T N R_{\text {trade }}$ have above definition and $t$ is the trading ratio. If the marginal cost of participating in the WQT program $\left(M C_{\text {trade }}\right)$ is less than the marginal cost of installing (or upgrading) WWTP $\left(M C_{\text {tech }}\right)$, developers can meet their $\overline{T N}$ requirements at a lower cost by buying credits from a WQT market.

$$
\left(T N R_{\text {tech }}, T N R_{\text {trade }}\right)= \begin{cases}\left(0, T N R_{u}\right) & \text { if } M C_{\text {trade }}<M C_{\text {tech }} \\ \left(T N R_{u}, 0\right) & \text { if } M C_{\text {trade }}>M C_{\text {tech }}\end{cases}
$$

Simply put, when urban developers find it less costly to purchase credits, rather than upgrade their plants, they demand credits.

On the supply side of the Jordan Lake WQT program, farmers who opt to participate in the program are required to install riparian buffers as a CP. Since participation in the Jordan Lake WQT program is voluntary for farmers, a farmer maximizes his/her profit by selling crops and TN reduction $\left(T N R_{f}\right)$ credits as follows:

$$
\max _{x, Z} \pi=P_{Y} Y(x)+P_{N} T N R_{f}(Z)-T C(Z)-r_{x} x
$$

where $\pi$ is profit, and $x$ and $Z$ are traditional crop production inputs and the inputs required for installing conservation practices, respectively. $\mathrm{P}_{\mathrm{Y}}$ is the price of crop $(\mathrm{Y})$, and $\mathrm{P}_{\mathrm{N}}$ is the price of TNR credits to the farmer and $r_{x}$ is the price of traditional cropping inputs. $T C(Z)$ includes the total cost of installing a riparian buffer, total opportunity cost (lost cropping profits), and the cost of maintaining and monitoring the installed buffer. Typically, not all of the pollution a farmer prevents is allowed to be sold as credits. Often credit is only given for pollution prevention above some baseline determined by the program. $T N R_{f}$ in Equation (4) indicates the amount of TN load reduction beyond the baseline that can be sold from installing a riparian buffer. That is: 


$$
T N R_{f}=T N_{r}-T N_{0}
$$

where $T N_{r}$ shows the TN load after installing riparian buffers and $T N_{0}$ is the baseline. In the Jordan Lake program, baseline is set to the average TN loads from 1997-2001. In the ideal market, the baseline wedge is unbinding; therefore $T N_{0}$ is set to zero and all $T N R_{f}$ can be sold. Farm supply of credits is determined by maximizing equation 3 . As $P_{N}$ goes up, so does the supply.

\subsection{A marginalized market}

The ideal market changes when wedges are added. Each wedge pushes supply and/or demand away from each other, reducing tradable credits. The addition of more wedges causes more shifts in supply/demand, and an increasingly marginalizes the market. In this section, we investigate the roles of four wedges in supply and demand that are often identified in the literature: baseline, transaction cost, trading ratio, and trading cost.

\subsubsection{Baseline}

Establishing a baseline is one of the first steps in implementing a WQT program. The baseline defines the amount of pollution reduction that must be achieved before WQT is allowed. Stephenson et al. (2010) and Ghosh et al. (2011) found that a baseline that is more stringent than current practices increases the cost of agricultural credit and the expenses of entering a trading program. A baseline can affect credit buyers by requiring a minimum threshold of abatement before allowing credits to be purchased, or affect credit suppliers by setting a minimum pollution reduction to be achieved before credits may be sold. The baseline truncates (eliminates) the lower end of the supply function by requiring a farmer to reduce the nutrient load up to the baseline at their own expense. Likewise, the baseline requirement truncates the upper portion of the demand function, requiring urban developers to achieve the first units of abatement by other

methods besides WQT (Duke et al. 2012; Savage and Ribaudo, 2014). Baseline could have a profound influence on the feasibility of a WQT market (EPA, 2007).

In our case study, we designed two baseline scenarios for the supply side of the Jordan Lake WQT program: (1) The control period (C): average 1997-2001 TN loads, and (2) Stringent Baseline (B): $92 \%$ of $\mathrm{C}$, which meets the $8 \%$ targeted reduction in loading stated for the Jordan Lake program. In both cases, pollution reduction is the difference between TN loads in the 
baseline and loading in 2012 after riparian buffers were installed (R). For the demand side, we applied the regulated storm water management baseline requirement to urban developers.

\subsubsection{Transaction cost}

Transaction costs are those additional costs on top of the price of the trade that would be required to make trades happen. The transaction costs associated with a given environmental policy can be divided into policy transaction costs (such as bureaucracies necessary to run the program) and market transaction costs (such as legal representation required for contracts) (Herath and Weersink, 1999). Adding either type of transaction cost increases the cost of participating in a WQT program for both urban developers and farmers (Woodward and Kaiser, 2002), and shifts or tilts both ideal demand and supply curves.

"A few studies have attempted to estimate transaction costs of environmental markets or conservation programs" (Chesapeake Bay Commission. 2012, pp. 26), prompting us to also make assumptions based on literature estimates. Galik et al. (2012), McCann and Easter (2000), and Heimlich (2005) estimated a range for transactions costs of between $10 \%$ and $50 \%$ of the other costs of generating credits. Fang et al. (2005) estimated a 35\% transaction cost factor for a nutrient trading program in the Minnesota River Basin. The Chesapeake Bay Commission (2012) adopted $38 \%$ adjustment factor for calculating transaction cost of nutrient trading program. For purposes in this study, we assumed transaction costs are $35 \%$.

\subsubsection{Trading cost}

Trading cost encompasses two influential components of a WQT program, including transaction costs and an adoption premium (AP), which are necessary costs for doing business in a WQT program. The innovation premium can be viewed simply as a premium over and above the direct costs and transaction costs that would be necessary to prompt a producer to adopt a system. The concept of an AP was distinguished from transaction costs by Motallebi et al. (2016) and is meant to account for abstract factors that are not typically included in transaction costs (Peterson et al. 2007). These costs are difficult to assess, such as how much value a farmer puts on their lack of trust for government programs or hesitance to adopt unfamiliar systems (Breetz et al. 2005; Mariola, 2012). Moreover, sometimes a WQT program is too new to permit trades and the 
new trading rules and regulations produce uncertainties for the WQT participants (Morgan and Woverton, 2005; Shortle, 2013a, 2013b).

We measured the AP by subtracting installation cost and transaction cost from a farmers' willingness to accept (WTA) a payment to adopt a CP (see Motallebi et al. 2016 for more details). WTA was elicited from an in-person interview with 90 farmers whose farms are located in the Jordan Lake Watershed (O'Connell et al. 2016). For example, if a farmer's WTA was $\$ 5,000$ to adopt a $\mathrm{CP}$, and the cost to implement and maintain the CP was $\$ 2,000$, with $35 \%$ transaction costs $(\$ 700)$, the farmer is asking for a premium, or additional incentive of $\$ 2,300$ $(=5,000-2,000-700)$. Adding an AP tilts the supply curve to the left, decreasing the amount of the available credits.

\subsubsection{Trading ratio}

Trading ratio $(t)$ is "equal to the marginal rate of substitution of emissions between two sources which ensures no net change in ambient pollution" (Horan and Shortle, 2011, pp: 61). EPA (2007) indicates that the trading ratios encompass the equivalency ratios to adjust for trading different forms of the same pollutant, and uncertainty ratios to adjust for uncertainties associated with NPS trades (EPA, 2007). The stochastic nature of NPS emission makes the loading reduction efficiency of a given $\mathrm{CP}$ uncertain and increases the risk that water quality goals may not be achieved (Horan, 2001). A high trading ratio could reduce the economic attractiveness of trading programs because it discounts credits from NPSs (Corrales et al. 2013) and tilts WQT demand to the left.

For equivalency, we derived individualized delivery ratios for every unique field using SPARROW ${ }^{1}$ coefficients (Smith et al. 1997) on the supply side. To account for the trading ratio associated with uncertainty, we used chance constrained programming (CCP) on the demand side (Charnes and Cooper, 1965). Uncertainty makes the WQT model stochastic. CCP addresses uncertainty by specifying a confidence level $(\alpha)$ for uncertain constraints. Essentially, our uncertainty ratio accounts for the uncertainty of achieving at least $\alpha \%$ of a pollution abatement goal (Ghosh and Shortle, 2009). Zhang and Wang (2002) utilized the CCP method to calculate the trading ratio of a WQT program in Taihu Lake in China.

\subsection{Case study: Jordan Lake water quality trading program}

\footnotetext{
${ }^{1}$ SPAtially Referenced Regressions On Watershed attributes
} 
Jordan Lake has been declared hyper-eutrophic since its impoundment in 1983 (NCDEQ, 2014). In its 2005 draft Cape Fear Basin Plan, NC Division of Water Quality (DWQ) identified the entire Jordan Lake Watershed as nutrient-impaired based on chlorophyll $a$ data, and placed it on the Clean Water Act 303(d) list and requiring a Total Maximum Daily Load (TMDL) to meet the criterion for Chlorophyll $a$. A WQT program has been suggested by the North Carolina Department of Environment and Natural Resources to address water quality issues facing this rapidly urbanizing watershed, and to reduce nutrient delivery to Jordan Lake (NCDENR, 2013). In this study, we focus on the Haw sub-watershed where trading is most likely.

\subsubsection{Supply from farmers in the Haw sub-watershed}

The Jordan Lake WQT program encourages farmers to adopt and maintain riparian buffers close to streams on their farms (NCDENR, 2013). Riparian buffers preserve land near streams with permanent vegetation to reduce the discharge of nutrient and sediment lost from agricultural fields, improve water quality, and provide other ecosystem services (e.g. wildlife habitat). Several cost-related assumptions are included in our WQT model. First, based on the Jordan Lake WQT program rules (hereafter referred to as "Jordan Lake rules") (NCDEQ, 2014), riparian buffers should be installed on the edge of fields, adjacent to a stream. The required width of the buffer is $15.24 \mathrm{~m}$. We assumed the opportunity cost for crop and livestock farmers is equal to the net returns loss from crops or hay that could not be harvested due to devoting a portion of the field to the riparian buffer. Yield and price data for NC crops and hay were obtained from National Agricultural Statistics Service (NASS, 2014). The costs of producing hay and crops were extracted from NC State University and A\&T State University Cooperative Extension (2014). A discount rate of $4.6 \%$ in perpetuity was used to annualize the investment costs (NRCS, 2009). Installation costs were estimated at $\$ 1,110$ per ha for crop producers and $\$ 5,400$ per ha for livestock farmers (NRCS, 2011).

We used the Soil and Water Assessment Tool (SWAT 2012) (Arnold et al. 1998) to simulate the TN loads from agricultural fields and their reductions due to installing riparian buffers. TN loads were then multiplied by delivery ratios from SPARROW to determine the amount of abatement to Lake Jordan for each field. SWAT is a semi-distributed process-based watershed model which has been used in the literature extensively for simulating hydrologic and water quality processes as well as water quality benefits of agricultural conservation practices 
(Arabi et al., 2007; Tasdighi et al., 2016; SWAT Literature Database, 2016). The SWAT model has predefined routines for evaluating the effects of agricultural conservation practices such as field strips, riparian buffers, grassed waterways. The model was calibrated for the period of 1997 to 2007 using the daily stream flow and monthly TN loads at 5 stations across the watershed producing good to very good results based on the criteria described in Moriasi et al (2007). The Nash-Sutcliff efficiency was $>0.60$ and |relative error $\mid<17 \%$. The performance of the model was then tested for the period of 2008 to 2012 generating satisfactory to good results (NashSutcliff efficiency $>0.53$ and $\mid$ relative error $\mid<15 \%)$.

We found 10,835 fields located in the Haw sub-watershed based on the available common land units dataset (CLUs) ${ }^{2}$. According to the Jordan Lake rules, fields with forest land were ineligible for WQT (NCDENR, 2013), which qualified 3,753 out of 10,835 fields as eligible for trades. The calibrated SWAT model was used to simulate the TN loads on eligible fields for the control-period (C), 1997-2001, and in 2012 after the riparian buffers had been installed (R) (Motallebi, 2015). We design two baseline scenarios for individual farmers participating in the Jordan Lake WQT program. Our results show how changing the baseline scenario will change the amount of total available WQT credit in this region.

\subsubsection{Demand from urban developers}

According to Jordan Lake rules, new urban developers are responsible for installing one WWTP, including bio-retention, sand filters, ponds, or wetlands to reduce TN loads to achieve their storm water management requirement. If the urban developer's load reduction after installing the WWTP is less than the total required reduction, the developer has two options. They can either upgrade or expand their current WWTP, or trade with farmers to achieve the required reductions.

In this study, the cost of installing WWTPs, including construction cost, 20-year maintenance cost, and opportunity cost were extracted from a report on the economics of structural stormwater best management practices (BMPs) for NC (Wossink and Hunt, 2003). Net present value (NPV) of these costs, with a discount rate of $4.6 \%$, was used to calculate the total cost of installing or upgrading a WWTP in 2014. Also, we used the Jordan Lake Nutrient Loading Accounting Tool (NCDENR, 2007) to calculate the TN loads reduction after installing

\footnotetext{
2 "A Common Land Unit (CLU) is the smallest unit of land that has a permanent, contiguous boundary, a common land cover and land management, a common owner and a common producer in agricultural land associated with USDA farm programs." (USDA, 2012).
} 
or upgrading WWTPs for a new urban development. Details about the cost of WWTP's are provided in Table 1. The required TN threshold for total storm water management for urban developments (i.e., urban developers' baseline) in the Haw sub-watershed is $4.26 \mathrm{~kg} / \mathrm{ha} / \mathrm{yr}$. We used the results from a 17.5 ha residential and commercial development located in the city of Durham as a proxy for the region. The new urban developer WWTP installation costs are reported in Table 1. As shown, a 1.6-ha residential portion of the new urban development is required to reduce its pollution by $2.7 \mathrm{~kg} / \mathrm{ha} / \mathrm{yr}$. Currently, the bio-retention pond used by the developer reduces $\mathrm{TN}$ by only $2.35 \mathrm{~kg} / \mathrm{ha} / \mathrm{yr}$. Therefore, the developer needs to reduce the load by an additional $0.34 \mathrm{~kg} / \mathrm{ha} / \mathrm{yr}$, either by expanding the current WWTP or by trading with farmers. If the developer chooses the first option, they require $0.62 \mathrm{~kg}$ offset per year for their 1.6 ha portion. For this portion, the additional cost of expanding the current WWTP to reach the required reduction of $0.62 \mathrm{~kg}$ is $9,946(\$ / \mathrm{kg})$. Likewise, the other portions of this development project would cost $\$ 12,969$, $\$ 42,240$, and $\$ 56,074$ per kilogram of TN load reduction to expand their current WWTPs for reaching the required $\mathrm{TN}$ reduction.

According to the Jordan Lake Watershed model report (TETRA TECH, 2014), the imperviousness between 1999 and 2010 increased by 13,450 ha in the Haw sub-watershed, or by 1,223 ha per year. We assume that the imperviousness growth rate indicates the urban development growth rate. For simplicity and clarity, we assume that urban development in the Haw sub-watershed will continue to grow at 1,223 ha per year, and that all growth will have the same impact on TN loads in our case study.

\section{Results}

\subsection{The ideal market}

The ideal supply and demand for the Jordan Lake program is illustrated by the solid lines in Figure 2 and given in Table 2. The supply curve depicts the cost to supply credits from the 3,753 fields by installing a riparian buffer. It slopes up because credits from fields close to the lake are relatively cheap compared to credits from fields that are farther away when TN delivery to the lake is considered. Demand is plotted from Table 1 and slopes down because at higher prices buyers would demand less, opting to upgrade their plants rather than buy credits. The 
equilibrium quantity traded in an ideal market with no wedges, where supply crosses demand, is $1,916 \mathrm{~kg}$, with an average price of $\$ 4,778$ per credit.

The social value of a program can be determined by the amount of social surplus it generates. Buyers that pay a price lower than they were willing to pay, the region above price and below the demand curve in Figure 2, earn a consumer surplus (CS). That is, if you were willing to pay $\$ 100$ but only had to pay $\$ 70$ based on the equilibrium price, you would have $\$ 30$ of surplus to spend on something else. Likewise, producers that receive a higher price than they needed to supply credits, the region below price and above supply, earn a producer surplus (PS). When added together, this market yields a social surplus (SS) of $\$ 36.6$ million. SS can be thought of like new money generated for society by adding the trading program, which is a valuable welfare measure of a program's success.

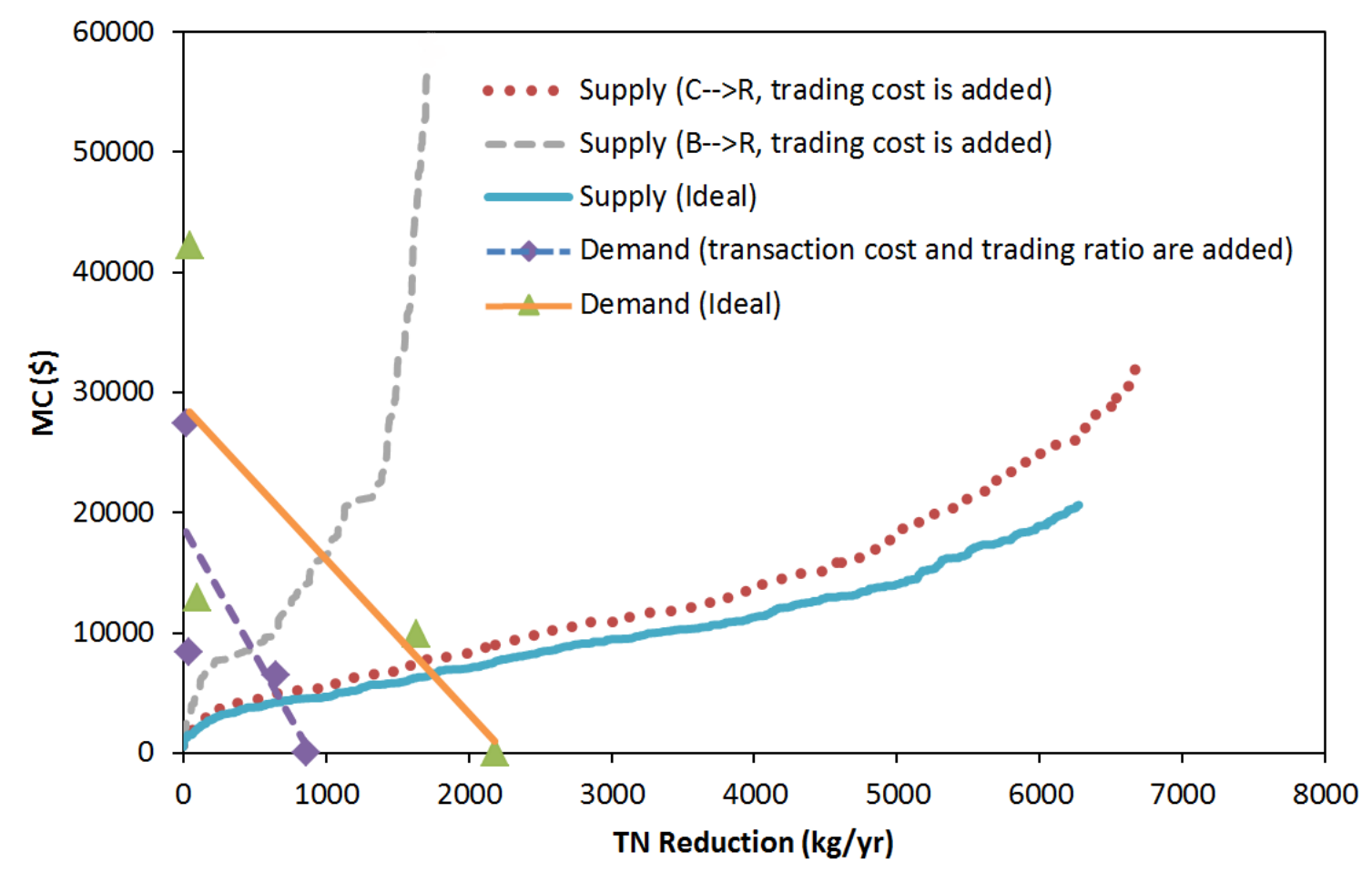

Fig. 2. Supply and demand, with and without wedges, for WQT program in Jordan Lake, NC. C is the TN baseline based on the control period, 1997-2001, B is $92 \%$ of C, and R is the TN load after conservation practices have been installed.

\subsection{Adding wedges to the supply side}

We redraw supply and demand in Figure 2 to account for one wedge at a time and for all wedges together. Supply shifts in, as shown, when baseline and trading costs are added, and demand 
shifts in when transaction costs and trading ratios are added. Each of these shifts drives the price up and supply traded down.

On the supply side, credit producers (farmers implementing CP) in the Jordan Lake Watershed face two potential baselines that effect trading as follows:

Liberal baseline: the difference between average TN loads for the control period from 19972001 (C) and after riparian buffer installation in 2012 (R), or $C \rightarrow R$, and

Stringent baseline: the difference between $92 \%$ of the control-period (B), and after installation of riparian buffers $(\mathrm{R})$, or $(\mathrm{B} \rightarrow \mathrm{R})$.

Implementing a baseline truncates credit supply by reducing the number of eligible farmers that can participate in the program and concurrently raises the cost of trading. A total of 3,659 fields are eligible to participate in Jordan Lake's WQT program under the liberal baseline, while only 806 fields are eligible in the more stringent scenario. As shown in Table 3, the maximum supply of credits is $1,991 \mathrm{~kg}$ for the $\mathrm{B} \rightarrow \mathrm{R}$ scenario and increases to $9,967 \mathrm{~kg}$ for the $\mathrm{C} \rightarrow \mathrm{R}$ scenario. The cost of cheapest unit (first field in at the bottom of the supply curve) is $\$ 1,148$ with the liberal baseline and $\$ 521$ with a stringent baseline, and rises to several million dollars for the last unit of TN reduced (top of the supply curve). Buying one unit of TN load reduction under the $\mathrm{C} \rightarrow \mathrm{R}$ scenario is cheaper than buying the same amount of reduction under $\mathrm{B} \rightarrow \mathrm{R}$ scenario due to the high baseline requirement.

Inclusion of trading costs (transaction cost plus AP) also reduces the quantity of trades. The results of adding trading costs are shown in Tables 2 and 3. Results based on Motallebi et al. (2016) show that livestock and crop farmers' AP was 2.35 and 2.36 times higher, respectively, than the installation cost of the riparian buffers. The minimum cost of trading, after adding the trading cost increases from 1,148 to $1,320(\$ / \mathrm{kg})$ for the liberal baseline and from 521 to 601 $(\$ / \mathrm{kg})$ with a stringent baseline. On average, costs increase by about $77 \%$ and $85 \%$ respectively when trading costs are added.

Table 3 shows how wedges individually and jointly affect a WQT program. For example, simultaneous addition of a stringent baseline and trading cost to the ideal WQT market will increase the price of each credit by $\$ 799$ (the difference between $\$ 1,320$ and $\$ 521$ ), while adding only trading cost to the ideal scenario will raise the minimum price of each credit by $\$ 80$ (the difference between $\$ 521$ and \$601). That is, implementing a stringent baseline or adding trading cost individually will raise the minimum credit price by $220 \%$ and $110 \%$ respectively, compared 
to the ideal situation. Adding these two wedges to the model simultaneously raises the minimum price of each credit by $250 \%$. The effect of these wedges on the market equilibrium are presented

in Table 2 and shown in Figure 2. The combined effect of both wedges together would reduce tradable emissions from $1,916 \mathrm{~kg}$ of $\mathrm{TN}$ to $775 \mathrm{~kg}$ of $\mathrm{TN}$ in the watershed. SS is reduced from 36.6 to 34.1 million dollars with introduction of the trading cost wedge (about $7 \%$ reduction) and to 14.3 million dollars with simultaneous inclusion of baseline and trading cost (about $60 \%$ reduction) for Haw sub-watershed.

\subsection{Adding wedges to the demand side}

Unlike producers, there is no ambiguity about whether urban developers need to achieve a baseline before trading. The Jordan Lake rules explicitly indicate new urban developers must first implement required WWTPs before trading. The estimated demand therefore already includes that requirement. A trading ratio $(t)$ and transaction cost are the two main wedges that we add to the demand side. The uncertainty component of TN load reduction efficiency in the trading ratio of our study was calculated using the CCP method. CCP minimizes the total abatement costs with a constraint of targeted emission (see Wang et al. 2004 for more details). In this study a trading ratio greater than 1.0 was expected. Shortle $(1987,1990)$ noted that a $t>1$ is appropriate when the NPS loading variance increases by the level of NPS abatement effort. Assuming the probability of achieving the TN load reduction in this program is $95 \%$, the $t$ would be 2.5 , indicating that an urban developer should buy $2.5 \mathrm{~kg}$ of credits to offset one-unit of $\mathrm{TN}$ emission to the lake.

Similarly to the supply side, we added a 35\% adjustment factor to the demand side of WQT program to include the transaction cost. The impact of demand wedges are shown in Table 2 and Figure 2. The combined effect of both supply wedges and trading ratio was to reduce the tradable emission of TN to $656 \mathrm{~kg}$, and to reduce welfare (SS) by nearly 80\% to 7.8 million dollars. The combined effect of all considered wedges on both supply and demand sides reduced the tradable emission to $486 \mathrm{~kg}$ of TN and welfare to 5.7 million dollars (nearly $85 \%$ reduction).

Table 2 displays the changes in the WQT market equilibrium in different scenarios. The maximum amount of credit provided at the lowest price will happen in the ideal market in $1,916 \mathrm{~kg} \mathrm{TN} / \mathrm{yr}$ at a price of $\$ 4,778$. Adding trading cost (i.e., transaction cost and AP) will drop the amount of tradable credits by about $7 \%$ and increase the equilibrium price by $47 \%$. A 
stringent baseline will reduce the potential number of fields that can supply credits from 3,659 to 806 , and increase the credit prices. All wedges combined reduce the tradable credit by about $75 \%$ from $1,916 \mathrm{~kg} / \mathrm{yr}$ to $486 \mathrm{~kg} / \mathrm{yr}$, and increase the credit price by about $50 \%$ from $\$ 4,778$ to $\$ 6,978$; welfare is reduced by about $85 \%$ from $\$ 34.1$ million to $\$ 5.7$ million. These results are illustrated in

Figure 2, where the impact of wedges is shown through a series of shifts in demand and supply.

\section{Additional Considerations}

The ideal Jordan Lake WQT market is severely weakened by the four wedges that we considered, but still has a positive price and quantity. This implies the market is marginalized, but still feasible. However, the actual program has another problem that is not mentioned as a wedge in the literature. Demand and supply are seriously mismatched. Demand will consume all of the credits that agriculture can provide at reasonable cost in a single year. The remaining supply will be so small and so expensive that the market is infeasible after the first or second year. Therefore, a WQT program in the Jordan Lake Watershed is virtually impossible because the annual demand is about two-thirds as much as what agriculture can ever supply.

\section{Conclusion}

Despite their attractiveness on paper, cost effective conservation practices such as WQT programs may not always be the most applicable approaches. Implementing these programs requires knowledge that comes from a well-defined economic model that includes as many implementation wedges as appropriate. In this paper, a WQT economic model was developed for Jordan Lake Watershed, NC. Four wedges, baseline, transaction cost, trading cost, and trading ratio, were added. The results revealed that adding all wedges simultaneously will reduce the tradable credits by three quarters and society's welfare by $84 \%$. Therefore, the results indicate that the four wedges marginalize the market in Jordan Lake Watershed NC, but alone do not result in zero credits traded. However, spending the time, effort, and financial resources on a program for so few credits is likely infeasible. In addition, the total amount of supply is inadequate to keep up with demand over time, rendering the market unviable over longer time periods. 
The Jordan Lake WQT market offers a perfect example of a program moving forward without sufficient information and analysis. Had the analysis been done prior to implementation, the North Carolina State may have saved time and money. The framework offered here is costeffective and can be done in most locations with current data and modeling tools.

Overall, while the WQT program in Jordan Lake watershed, NC, shows some potential, it does not appear to be applicable. Assessing all effective wedges on the WQT program will assist policy makers in evaluating the likely success or failure of this policy for Jordan Lake, NC.

This study helps show policy makers how to navigate the growing number of studies that find wedges in order to determine if WQT is viable at a location, and if so, how to reduce marginalization of the WQT market by wedges through thoughtful program design.

\section{Acknowledgements}

This research was financially supported by a grant from USDA National Institute of Food and Agriculture Integrated Water Quality Grant award \# 2011-05151 and USEPA grant RD835570. Its contents are solely the responsibility of the grantees and do not necessarily represent the official views of the USDA or USEPA. Our thanks to Richard Gannon (NC Department of the Environment and Natural Resources, Division of Water Resources) for providing information on the trading program. 


\section{References}

Arabi, M., Frankenberger, J.R., Engel, B.A., Arnold, J.G., 2007. Representation of agricultural conservation practices with SWAT. J. Hydrol. Process. (22), 3042-3055. doi:10.1002/hyp.6890.

Arnold, J.G., Srinivasan, R., Muttiah, R.S., Williams, J.R., 1998. Large-area hydrologic modeling and assessment: Part I. Model development. J. Am. Water Resour. Assoc. 34(1), 7389.

Breetz, H.L., Fisher-Vanden, K., Garzon, L., Jacobs, H., Kroetz, K., Terry, T., 2004. Water quality trading and offset initiatives in the US: A comprehensive survey. http://www.dartmouth.edu/\%7Ekfv/waterqualitytradingdatabase.pdf.

Breetz, H.L., Fisher-Vanden, K., Jacobs, H., Schary, C., 2005. Trust and communication: Mechanisms for increasing farmers' participation in water quality trading. Land Econ. 81(2), 170-190.

Charnes, A., Cooper, W.W., 1965. Chance-constrained programming. Manage. Sci. 6, 73-79.

Chesapeake Bay Commission, 2012. Nutrient credit trading for Chesapeake Bay, An economic study. http://www.chesbay.us/Publications/nutrient-trading-2012.pdf.

Corrales, J., Naja, G.M., Rivero, R.G., Miralles-Wihelm, F., Bhat, M.G., 2013. Water quality programs towards solving environmental pollution problems. Irrigation and Drainage. 62(S2), 72-92.

Duke, J.M., McGrath, T., Fiorellino, N.M., Monteith, T.S., Rosso, E., 2012. Additionality in water quality trading: Evidence from Maryland's nutrient offset program. Department of Applied Economics and Statistics Working Paper RR14-06, University of Delaware, Newark, DE.

Faeth, P., 2000. Fertile ground: Nutrient trading's potential to cost-effectively improve water quality. World Resources Institute, Washington, DC.

Fang, F., Easter, K.W., Brezonik, P.L., 2005. Point-nonpoint source water quality trading: A case study in the Minnesota River basin. J. Am. Water Resour. Assoc. 41(3), 645-657.

Galik, C.G., Cooley, D., Baker, J.S., 2012. Analysis of the production and transaction costs of forest carbon offset programs in the USA. J. Environ. Manage. 112, 128-36.

Ghosh, G., Ribaudo, M., Shortle, J., 2011. Baseline requirements can hinder trades in water quality trading programs: Evidence from the Consetoga Watershed. J. Environ. Manage. 92(8), 2076-2084. 
Ghosh, G., Shortle, J., 2009. Water quality trading when nonpoint pollution loads are stochastic. Institute for Future Energy Consumer Needs and Behavior (FCN). FCN Working Paper No. 10/2009.

Greenhalgh, S., Selman, M., 2012. Comparing water quality trading programs: What lessons are there to learn? J. Region. Analysis Policy 42(2), 104-125.

Heimlich, R.E., 2005. The policy-related transactions costs of land conservation in the U.S.: Evolution and comparison between programs. Presented at the OECD Workshop on PolicyRelated Transaction Costs, Paris, France.

Hennessy, D.A., Feng, H., 2008. When should uncertain non-point emissions be penalized in a trading program? Am. J. Agr. Econ. 90(1), 249-255.

Herath, P.B., Weersink, A., 1999. Transaction cost, economic instrument and environmental policy. Annual Meeting of American Agricultural Economics Association, Nashville, TN, 8-11 Aug.

Hoag, D., Hughes-Popp, J.S., 1997. Theory and practice of pollution credit trading in water quality management. Rev. Agr. Econ. 19(2), 252-262.

Horan, R.D., 2001. Differences in social and public risk perceptions and conflicting impacts on point/nonpoint trading ratios. Am. J. Agr. Econ. 83, 934-941.

Horan, R.D., Shortle, J.S., 2011. Economic and ecological rules for water quality trading. J. Am. Water Resour. Assoc. 47(1), 59-69.

Jarvie, M., Solomon, B.D., 1998. Point-nonpoint effluent trading in watersheds: A review and critique. Environ. Impact Assess. Rev. 18, 35-157.

King, D., 2005. Crunch time for water quality trading. Choice, 20(1), 71-75.

King, D. M., Kuch, P.J., 2003. Will nutrient credit trading ever work? An assessment of supply and demand problems and institutional obstacles, environmental law reporter. Environ. Law Reporter 33, 10352-10368.

Malik, A.S., Letson, D., Crutchfield, S.R., 1993. Point/nonpoint source trading of pollution abatement: Choosing the right trading ratio. Am. J. Agric. Econ. 75, 959-967.

Mariola, M.J., 2012. Farmers, trust, and the market solution to water pollution: The role of social embeddedness in water quality trading. J. Rural Stud. 28, 577-589.

McCann, L., Easter, K.W., 2000. Estimates of public sector transaction costs in NRCS programs. J. Agr. Appl. Econ. 32(3), 555-563. 
Morgan, C., Wolverton, A., 2005. Water quality trading in the United States. National Center for Environmental Economics Working Paper no. 05-07, US Environmental Protection Agency.

Moriasi, D.N., J.G. Arnold, M.W. Van Liew, R.L. Bingner, R.D. Harmel, Veith. T.L., 2007. Model evaluation guidelines for systematic quantification of accuracy in watershed simulations. Transactions of the ASABE. 50:885-900. doi:10.13031/2013.23153.

Motallebi, M., 2015. Water quality trading in Jordan Lake, North Carolina: Economic, hydrological, behavioral, and ecological aspects. Doctoral dissertation. Colorado State University.

Motallebi, M., O’Connell, C., Hoag, D., Osmond, D.L., 2016. Role of conservation adoption premiums on participation in water quality trading programs. Water 8(6), 245. doi:10.3390/w8060245.

Natural Resources Conservation Service (NRCS), 2009. Rate for federal water projects. http://www.economics.nrcs.usda.gov/cost/priceindexes/rates.html.

NC State University and A\&T State University Cooperative Extension, 2014. Field crops publications. http://www.ces.ncsu.edu/publications-on-field-crops/.

Newburn, D.A., Woodward, R.T., 2012. An ex post evaluation of the Great Miami water quality trading program. J. Am. Water Resour. Assoc. 48(1), 156-169.

North Carolina Division of Water Resources (NCDENR), 2013. Jordan Lake rules. http://portal.ncdenr.org/web/jordanlake/tmdl.

North Carolina Division of Water Resources (NCDENR), 2007. Nutrient loading accounting tool. http://portal.ncdenr.org/web/jordanlake/implementation-guidance-archive.

North Carolina Division of Environmental Quality (NC DEQ), 2014. Jordan Lake water supply allocation. https://deq.nc.gov/about/divisions/water-resources/planning/basin-planning/mappage/cape-fear-river-basin-landing/jordan-lake-water-supply-allocation.

North Carolina Department of Environmental Quality. Jordan Lake background. http://portal.ncdenr.org/web/jordanlake/background.

North Carolina Department of Environmental Quality. Jordan Lake rules. http://portal.ncdenr.org/web/jordanlake/read-the-rules.

O’Connell, C., Motallebi, M., Osmond, D.L., Hoag, D., 2016. Trading on risk: The moral logics and economic reasoning of North Carolina farmers in water quality trading markets. Econ. Anthropo. 3(1), forthcoming, 
Peterson, J.M., Fox, J.A., Leatherman, J.C., Smith, C.M., 2007. Choice experiments to assess farmers, willingness to participate in a water quality trading market. Paper prepared for presentation at the American Agricultural Economics Association Annual Meeting, Portland, Oregon, 29 July 29-1 Aug., 2007.

Ribaudo, M.O., Gottlieb, J., 2011. Point-nonpoint trading: Can it work? J. Am. Water Resour. Assoc. 47(1), 5-14.

Ribaudo, M., Horan, R.D., Smith, M.E., 1999. Economics of water quality protection from nonpoint sources: Theory and practice. Agricultural Economic Report 782.

Savage, J., Ribaudo, M., 2014. Controlling non-additional credits from nutrient management in water quality trading programs through eligibility baseline stringency. Paper prepared for presentation at the Agricultural \& Applied Economics Association's 2014 AAEA Annual Meeting, Minneapolis, MN, 27-29 July, 2014.

Selman, M., Greenhalgh, S., Branosky, E., Jones, C. Y., Guiling, J., 2009. Water quality trading programs: An international overview. World Resource Institute Issue Brief No 1.

Shabman, L., Stephenson, K., 2002. Trading programs for environmental management: Reflections on the air and water experiences. Environ. Practice 4, 153-162.

Shortle, J., 1987. Allocative implications of comparisons between the marginal costs of point and nonpoint source pollution abatement. Northeast J. Agr. Res. Econ. 16:17-23.

Shortle, J., 1990. The allocative efficiency implications of water pollution abatement cost comparisons. Water Resour. Res. 26, 793-97.

Shortle, J., 2013a. Economics and environmental markets: Lessons from water quality trading. Agr. Resour. Econ. Rev. 42(1), 57-74.

Shortle, J., 2013b. Water quality trading: What have we learned? STAC Workshop on Water Quality Trading, Pennsylvania State University.

Smith, C.M., Peterson, J.M., Leatherman, J.C., Williams, J.R., 2012. A simulation of factors impeding water quality trading. J. Region. Analysis Policy 42(2), 162-176.

Smith, R.A., Schwarz, G.E., Alexander, R.B., 1997. Regional interpretation of water quality monitoring data. Water Resour. Res. 33(12), 2781-2798.

Smith, C.M., 2011. An analysis of alternative soil, nutrient, and water management strategies. Doctoral dissertation. Kansas State University. 
Stavins, R., 1995. Transaction costs and tradable permits. J. Environ. Econ. Manag. 29(1), 133148.

Stephenson, K., Norris, P., 1998. Water-based effluent trading: The nonpoint source challenge. Contemp. Econ. Policy 16, 412-421.

Stephenson, K., Shabman, L., 2010. Rhetoric and reality of water quality trading and the potential for market like reform. J. Am. Water Resour. Assoc. 47, 15-28.

Suter, J.F., Spraggon, J.M., Poe, G.L., 2011. Thin and lumpy: An experimental investigation of water quality trading. Economics Department Working Paper Series. http://works.bepress.com/john_spraggon/.

SWAT literature database. 2016. Available at: (https://www.card.iastate.edu/swat_articles/ ).

Tasdighi, A., Arabi, M., Osmond, D., 2016. The relationship between land use and vulnerability to nitrogen and phosphorus pollution in an urban watershed. J. Environ. Qual. doi: 10.2134/jeq2016.06.0239.

TETRA TECH, 2014. Lake B. Everett Jordan Watershed model report. ftp://ftp.tjcog.org/pub/planning/water/JordanAllocationModel/TTDataFiles/Documents/Model_D evelopment_Reports/Jordan_Watershed_Model_Report_July2014final.pdf.

U.S. Environmental Protection Agency, 2008. Water quality trading evolution. Final report. http://water.epa.gov/type/watersheds/trading/upload/wqt.pdf.

U.S. Environmental Protection Agency, 2007. Water quality trading toolkit for permit writers. http://water.epa.gov/type/watersheds/trading/WQTToolkit.cfm.

U.S. Environmental Protection Agency, 2004. Water quality trading assessment handbook. Can water quality trading advance your watershed's goals? http://water.epa.gov/type/watersheds/trading/upload/2004_11_08_watershed_trading_handbook_ national-wqt-handbook-2004.pdf.

U.S. Department of Agriculture, 2012. Common Land Unit (CLU) information sheet. www.fsa.usda.gov/Internet/FSA_File/clu_infosheet_2012.pdf.

U.S. Department of Agriculture, 2014. National Agricultural Statistics Services (NASS). http://www.nass.usda.gov/Quick_Stats/Ag_Overview/stateOverview.php?state=NORTH\%20CA ROLINA. 
Wang, X., Zhang, W., Yingna, H., Suju, L., 2004. Modeling and simulation of point-non-point source effluent trading in Taihu Lake area: Perspective of non-point sources control in China. Sci. Total Environ. 325, 39-50.

Willamette Partnership, 2012. Draft regional recommendations for the Pacific Northwest on water quality trading. http://willamettepartnership.org/wp-content/uploads/2014/09/PNW-JointRegional-Recommendations-on-WQT_ThirdDraft_2014-08-05_full1.pdf.

Woodward, R., Kaiser, R., 2002. Market structures for US water quality trading. Rev. Agric. Econ. 24, 366-383.

Wossink, A., Hunt, B., 2003. The economics of structural stormwater BMPs in North Carolina. UNC-WRRI-2003-344. WRRI Project 50260.

Zhang, W., Wang, X.J., 2002. Modeling for point-nonpoint source effluent trading: Perspective of non-point source regulation in China. Sci. Total Environ. 292, 167-176. 
Table 1. New urban developers' WWTP size and WWTP cost based on case study in Durham County, NC

\begin{tabular}{|c|c|c|c|c|c|c|c|c|c|c|}
\hline Development & Type & Size (ha) & Location & WWTP type & $\begin{array}{c}\text { Current } \\
\text { Reduction } \\
\text { (kg/ha/yr) }\end{array}$ & $\begin{array}{l}\text { Required } \\
\text { Reduction } \\
\text { (kg/ha/yr) }\end{array}$ & $\begin{array}{c}\text { Total } \\
\text { individual } \\
\text { offset (kg/yr) }\end{array}$ & $\begin{array}{c}\text { TC }(\mathrm{NPV}) \text { for } \\
\text { current } \\
\text { reduction }(\$)\end{array}$ & $\begin{array}{l}\text { TC }(\mathrm{NPV}) \text { for } \\
\text { required } \\
\text { reduction }(\$)\end{array}$ & $\begin{array}{c}\mathrm{MC} \\
(\$ / \mathrm{kg})\end{array}$ \\
\hline $\begin{array}{l}\text { The Villas at } \\
\text { Hope Valley }\end{array}$ & Residential & 1.62 & Durham & $\begin{array}{c}\text { BRC } \\
\text { w/IWS }\end{array}$ & 2.35 & 2.7 & 0.56 & 123,051 & 129,199 & 9,946 \\
\hline City Center & $\begin{array}{c}\text { Commercial } \\
\text { Building }\end{array}$ & 0.3 & Durham & BRC w/IWS & 4.9 & 7.6 & 0.81 & 35,612 & 45,338 & 12,969 \\
\hline $\begin{array}{c}\text { Hendrick } \\
\text { South Point }\end{array}$ & $\begin{array}{c}\text { Commercial } \\
\text { Auto Mall }\end{array}$ & 13.08 & Durham & $\begin{array}{l}2 \text { Ponds and } \\
\text { Sand Filter }\end{array}$ & 2.6 & 4.3 & 22.36 & $3,840,143$ & $4,767,501$ & 42,240 \\
\hline BCBS of $\mathrm{NC}$ & Commercial & 2.6 & Durham & $\begin{array}{l}\text { Wetland and } \\
\text { Sand Filter }\end{array}$ & 2.5 & 5.5 & 7.8 & 921,651 & $1,362,092$ & 56,074 \\
\hline
\end{tabular}

Table 2. Price and quantity of credits traded and social surplus in ideal and marginalized WQT market in Jordan Lake Watershed, NC

\begin{tabular}{|c|c|c|c|c|c|}
\hline Scenario & $\begin{array}{l}\text { Quantity } \\
\text { (kg/yr) }\end{array}$ & $\begin{array}{l}\text { Price } \\
\text { (\$) }\end{array}$ & $\begin{array}{l}\text { Consumer } \\
\text { Surplus } \\
(\mathrm{CS})^{*}(\$)\end{array}$ & $\begin{array}{l}\text { Producer } \\
\text { Surplus } \\
(\mathbf{P S})^{* * *}(\$)\end{array}$ & $\begin{array}{l}\text { Social } \\
\text { Surplus } \\
(\mathrm{CS}+\mathrm{PS})\end{array}$ \\
\hline Ideal demand and ideal supply & 1,916 & 4,778 & $35,118,134$ & $1,514,208$ & $36,632,342$ \\
\hline Ideal demand and adding trading cost to supply & 1,791 & 7,036 & $30,805,480$ & $3,306,587$ & $34,112,067$ \\
\hline Ideal demand and adding stringent baseline and trading cost to supply & 775 & 11,629 & $11,239,033$ & $3,089,318$ & $14,328,351$ \\
\hline $\begin{array}{l}\text { Adding trading ratio to the demand and adding stringent baseline and } \\
\text { trading cost to supply }\end{array}$ & 656 & 9,423 & $2,036,156$ & $5,768,229$ & $7,804,385$ \\
\hline $\begin{array}{l}\text { Adding transaction cost and trading ratio to the demand and adding } \\
\text { stringent baseline and trading cost to supply (marginalized market) }\end{array}$ & 486 & 6,978 & 919,815 & $4,803,161$ & $5,722,976$ \\
\hline
\end{tabular}

*CS is the difference between what urban developers are willing and able to pay for credits relative to its market price **PS is the benefit that farmers receive for selling the credits in the WQT market.

\footnotetext{
${ }^{3}$ Bio-retention cell with or without internal water storage
} 
Table 3. Total Nitrogen (TN) load reduction, Marginal Cost (MC), area and credit supply in different baseline scenarios

\begin{tabular}{|c|c|c|c|c|}
\hline & Scenario & $\begin{array}{c}\mathrm{MC}(\$ / \mathrm{kg}) \text { before adding trading } \\
\text { cost }\end{array}$ & $\begin{array}{c}\mathrm{MC}(\$ / \mathrm{kg}) \text { after adding trading } \\
\text { cost }\end{array}$ & Credit supply (kg) \\
\hline \multirow{2}{*}{$\begin{array}{c}\text { Min } \\
\text { (bottom of supply curve) }\end{array}$} & $\mathrm{B} \rightarrow \mathrm{R}$ & 1,148 & 1,320 & 1.1 \\
\hline & $\mathrm{C} \rightarrow \mathrm{R}$ & 521 & 601 & 0.7 \\
\hline \multirow{2}{*}{$\begin{array}{c}\text { Max } \\
\text { (top of supply curve) }\end{array}$} & $\mathrm{B} \rightarrow \mathrm{R}$ & $487,865,912$ & $904,963,792$ & 1,991 \\
\hline & $\mathrm{C} \rightarrow \mathrm{R}$ & $4,237,838$ & $6,571,250$ & 9,967 \\
\hline \multirow{2}{*}{ Average } & $\mathrm{B} \rightarrow \mathrm{R}$ & 937,915 & $1,664,703$ & 1,542 \\
\hline & $\mathrm{C} \rightarrow \mathrm{R}$ & 110,469 & 204,389 & 7,206 \\
\hline
\end{tabular}

$\mathrm{C}$ is the TN baseline based on the control period, 1997-2001, B is 92\% of C, and R is the TN load after conservation practices have been installed 